\title{
PENGARUH KREATIVITAS, LINGKUNGAN KELUARGA DAN JIWA ENTREPRENEUR TERHADAP NIAT BERWIRAUSAHA MAHASISWA STKIP PGRI TULUNGAGUNG
}

\author{
Muhammad Irwansyah ${ }^{1}$, Hari Subiantoro ${ }^{2}$ \\ ${ }^{1}$ Mahasiswa Program Studi Pendidikan Ekonomi STKIP PGRI Tulungagung \\ Email: muhammadirwansyah90@yahoo.co.id \\ ${ }^{2}$ DosenProgram Studi Pendidikan Ekonomi STKIP PGRI Tulungagung \\ Email: hrsubiyantoro@gmail.com
}

\begin{abstract}
This study aims to determine the influence of creativity, family environment and entrepreneurial spirit to the intention of entrepreneurship of students in the sixth semester of economic education in stkip pgri tulungagung.Populasi research semester VI students as many as 89 students, data collection methods using questionnaires, data analysis using multiple linear regression formula.Results analysis of data Test $t$ tuktilai value $t$ arithmetic (2.167) creativity variable (X1). The variable of the family environment $(\mathrm{X} 2)$ has a count value $(2,426)$. The entrepreneur (X3) entity variables have a tcount value (2.049.Can concluded partially that "the influence of creativity (X1), family environment (X2) and entrepreneur spirit (X3)entrepreneur(Y) student of economic education semester VI STKIP PGRI Tulungagung academic year 2017 /2018. Test F, show that valueFhitung $(23,464)$.This shows there are positive influence simultaneously creativity variable (X1) and environment family (X2) and entrepreneur spirit (X3) to entrepreneurship intention (Y) student of Economics Education Semester VI STKIP PGRI Tulungagung Academic Year 2017 / 2018.R2 is equal to 0,453 or effective sumbgan from three independent variable that is $45,3 \%$ to intention of entrepreneurship ( Y), and by $54.7 \%$ were explained by other factors that were not meticulously in this study.

Keywords: Creativity, Family Environment, Entrepreneurial Soul, Entrepreneurial
\end{abstract} Intention

\section{ABSTRAK}

Penelitian ini bertujuan untuk mengetahui pengaruh kreativitas, lingkungan keluarga dan jiwa entrepreneur terhadap niat berwirausaha mahasiswa semester VI pendidikan ekonomi di stkip pgri tulungagung.Populasi penelitian mahasiswa semester VI sebanyak 89 mahasiswa, metode pengumpulan data menggunakan angket,analisa data memakai rumus regresi linier berganda.Hasil analisis data Uji $t$ terbuktinilai t hitung (2.167) variabel kreativitas $\left(\mathrm{X}_{1}\right)$. Variabel lingkungan keluarga $\left(\mathrm{X}_{2}\right)$ memiliki nilait hitung $(2,426)$.Variabel jiwa entrepreneur $\left(\mathrm{X}_{3}\right)$ memiliki nilai thitung(2,049.Dapat disimpulkan secar parsial bahwa "adapengaruh kreativitas $\left(\mathrm{X}_{1}\right)$, lingkungan keluarga $\left(\mathrm{X}_{2}\right)$ dan jiwa entrepreneur $\left(\mathrm{X}_{3}\right)$ terhadap niat berwirausaha (Y) mahasiswa pendidikan ekonomi semester VI STKIP PGRI Tulungagung tahun akademik 2017/2018.Uji F, menunjukkan bahwa nilaiF $F_{\text {hitung }}(23,464)$. Hal ini menunjukkan ada pengaruh positif secara simultan variabel kreativitas $\left(\mathrm{X}_{1}\right)$ dan lingkungan keluarga $\left(\mathrm{X}_{2}\right)$ dan jiwa entrepreneur $\left(\mathrm{X}_{3}\right)$ terhadap niat berwirausaha $(\mathrm{Y})$ mahasiswa Pendidikan Ekonomi Semester VI STKIP PGRI Tulungagung Tahun Akademik 2017/2018. $\mathrm{R}^{2}$ adalah sebesar 0,453 atau sumbgan efektif dari ketiga 
variabel bebas yaitu 45,3\% terhadap niat berwirausaha (Y). dan sebesar 54,7\% di jelaskan oleh faktor-faktor lain yang tidak di teliti dalam penelitian ini.

Kata kunci : Kreativitas, Lingkungan Keluarga, Jiwa Entrepreneur, Niat

Berwirausaha

\section{PENDAHULUAN}

Pendidikan merupakan hal yang sangat penting dalam mengupayakan peningkatan kualitas sumber daya manusia (SDM).Kualitas SDM yang baik diharapkan dapat mengisi lapangan-lapangan pekerjaan yang sesuai dengan keahlian masing-masing.Masyarakat beranggapan dengan menempuh pendidikan tinggi dapat memperoleh pekerjaan yang diinginkan dengan harapandapat meningkatkan tarafhidup mereka.Namun, hal tersebut tidak terlepas dari kendala terbatasnya ketersediaan lapangan pekerjaan.Jumlah lulusan yang semakin banyak sehingga menyebabkan tidak terserapnya tenaga kerja. Hal ini dikarenakan sistem pembelajaran yang diterapkan oleh perguruan tinggi masihberorientasi kebidang akademik sehingga lebih terfokus bagaimana menyiapkan mahasiswa yang cepat lulus dan mendapatkan pekerjaan,bukan lulusan yang siap menciptakan pekerjaan.Dari hal tersebut sangat diperlukan pemahaman, khususnya bagi mereka yang berada dibangku pendidikan, bahwa pentingnya pendidikan kewirausahaan sebagaiawal pembentukan karakter agar mahasiswa dapat mampu hidup mandiri, tidak lagi terfokus untuk mencari kerja saja, upaya tersebut perlu dilakukan untuk meminimalisir pengangguran lulusan perguruan tinggi.

Menurut Chimucheka (2013) seperti yang dikutip oleh Adnyana \& Purnami, (2016) menyatakan bahwa "Salah satu faktor pendorong pertumbuhan kewirausahaan di suatu negara terletak pada peranan universitas melalui penyelenggaraan pendidikan kewirusahaan". Hal ini dikarenakan Jumlah lulusan perguruan tinggi yang tidak seimbang dalam penerimaan lapangan kerja membuat tidak sedikit lulusan perguruan tinggi yang menjadi pengangguran, serta masih berfikir untuk menjadi pekerja dibanding membuat lapangan kerja.

Menurut Imam Ghozali, S.Psi. \& Dr. Alimatus Sahrah, M.M., (2015). Niat berwirausaha juga dipengaruhi oleh beberapa faktor baik berasal dari faktor 
kepribadian yang berupa kreativitas serta inovasi dan faktor lingkungan yang berupa lingkungan keluarga, lingkungan sekolah dan lingkungan masyarakat.Niat berwirausaha dapat diperoleh dengan berbagai hal, misalnya dengan sifat kreatif yang dimiliki orang tersebut, dan lingkungan keluarga dimana orang tersebut tinggal.

Fatmawati (2013) mengungkapkan "Kreativitas berwirausaha bisa berkembang pada setiap mahasiswa karena adanya faktor-faktor diatas yang menjadi pendukungnya. Adanya rangsangan mental yang terdiri dari bermacammacam ciri-ciri pribadi kreativitas, iklim dan kondisi lingkungan yang baik, peran guru atau dosen mahasiswa yang membimbing dalam proses pembelajaran dan peran orang tua dalam mendidik mahasiswa sehingga akan tumbuh kreativitas pada dirinya".

Menurut Khairani (2014:194) seperti yang dikutip di Aini, Santosa, \& Hamidi (2017) Lingkungan keluarga adalah lingkungan sebagai pendidikan utama yang pertama kali diterima oleh seorang anak, karena dalam keluarga inilah anak pertama kali mendapatkan pendidikan dan bimbingan setelah mereka dilahirkan.

Menurut Kasmir (2009: 16-17) Entrepreneur adalah orang yang berjiwa berani mengambil risiko untuk membuka usaha dalam berbagai kesempatan.Jiwa kewirausahaan mendorong minat seseorang untuk mendirikan dan mengelola usaha secara professional.Menumbuhkan jiwa entrepreneur para mahasiswa perguruan tinggi dipercaya sebagai alternatif untuk meminimalisir tingkat pengangguran, karena banyak yang berharap para sarjana dapat menjadi wirausahawan muda terdidik dan mampu merintis usahanya sendiri melalui pengetahuan yang diperoleh dari pendidikannya.

Berdasarkan hasil wawancara peneliti dengan beberapa mahasiswa semester VI di STKIP PGRI Tulungagung pada tanggal 05 april 2018 diperoleh keterangan terkait keputusan mahasiswa setelah lulus kuliah, yaitu lebih memilihuntuk mencari pekerjaan dari pada membuka lapangan pekerjaan sendiri. Salah satu alasan mereka memilih bekerja pada orang lain atau sebagai karyawan yaitu tidak memikirkan laba dan rugi yang akan dialami ketika usaha yang 
Irwansyah, Subiantoro. Pengaruh Kreativitas, Lingkungan Keluarga Dan Jiwa Entrep...

dijalankan mengalami pasang surut dalam berwirausaha, sedangkan mahasiswa semester VI sudah menempuh mata kuliah kewirausahaan dan praktik kewirausahaan yang dibekali dengan ilmu pengetahuan baik teori berwirausaha maupun pengalaman dalam berwirausaha.

Penelitian yang dilakukan oleh Lilis Maryati (2017), dengan judul "Pengaruh Pengetahuan Kewirausahaandan Lingkungan Keluarga terhadap Niat Berwirausaha siswa di SMK Negeri 4 Surakarta Tahun Ajaran 2016/2017'bahwa terdapat pengaruh yang positif dan signifikan antara pengetahuan kewirausahaan dan lingkugan keluarga terhadap niat berwirausaha.

Berdasarkan latar belakang yang telah dipaparkan diatas, peneliti tertarik untuk melakukan penelitian dengan judul "Pengaruh Kreativitas, Lingkungan Keluarga dan Jiwa Entrepreneur Terhadap Niat Berwirausaha Mahasiswa Pendidikan Ekonomi Semeter VI di STKIP PGRI Tulungagung Tahun Akademik 2017/2018". Dengan tujuan penelitian sebagai berikut:

1. Mengetahui adakah pengaruh kreativitas terhadap niat berwirausaha mahasiswa Pendidikan Ekonomi Semester VI STKIP PGRI Tulungagung Tahun Akademik 2017/2018.

2. Mengetahui adakah pengaruh lingkungan keluarga terhadap niat berwirausaha mahasiswa Pendidikan Ekonomi Semester VI STKIP PGRI Tulungagung Tahun Akademik 2017/2018.

3. Mengetahui adakah pengaruh jiwa entrepreneur terhadap niat berwirausaha mahasiswa Pendidikan Ekonomi Semester VI STKIP PGRI Tulungagung Tahun Akademik 2017/2018.

4. Megetahui adakah pengaruh kreativitas, lingkungan keluarga dan jiwa entrepreneur terhadap niat berwirausaha mahasiswa Pendidikan Ekonomi Semester VI STKIP PGRI Tulungagung Tahun Akademik 2017/2018.

\section{METODE PENELITIAN}

Metode penelitian kuantitatif dapat diartikan sebagai metode penelitian yang berlandaskan pada filsafat positivisme, digunakan untuk meneliti pada populasi atau sampel tertentu, teknik pengambilan sampel pada umumnya diambil 
secara random, pengumpulan data menggunakan instrumen penelitian, analisis data bersifat kuantitatif/statistik dengan tujuan untuk menguji hipotesis yang telah ditetapkan (Sugiyono, 2016: 14 ).Penelitian ini juga menggunakan rancangan penelitian non eksprimen yang bersifat korelasional.

Subjek penelitiannya adalah mahasiswa STKIP PGRI Tulungagung Prodi Pendidikan Ekonomi semester VI tahun akademik 2017/2018.Jumlah sampel adalah keseluruhan mahasiswa semester VI yang berjumlah 89 .

Adapun metode pengumpulan data menggunkan angket, yang bertujuan untuk memperoleh data mengenai kreativitas, lingkungan keluarga dan jiwa entrepreneur terhadap niat berwirausaha, pernyataan dalam angket disajikan dalam bentuk skala likert.

Analisis menggunakan uji regresi linier berganda, pengujian hipotesis menggunakan uji koefisien determinasi $\left(\mathrm{R}^{2}\right)$, uji parsial (ujii t), dan uji simultan (uji F), sedangkan pengelolaan data menggunakan Progam SPSS 16

\section{HASIL dan PEMBAHASAN}

1. HASIL

A. Regresi Linier Berganda

Analisis regresi linier berganda di gunakan untuk membuktikan sejauh mana pengaruh dukungan keluarga dan pengetahuan kewirausahaan terhadap kesiapan berwirausaha. Hasil analisis regresi linier berganda dapat di lihat pada kolom unstandardized coefficients (merupakan regresi yang dihasilkan dengan menggunakan variabel yang tidak distandarisasi) pada bagian B (nilai konstan) dan standart eror(nilai maksimal kesalahan yang terjadi dalam memperkirakan ratarata populasi berdasarkan sampel), kolom b menunjukkan koefisien $b$ yaitu nilai yang menjelaskan bahwa Y (variabel terikat) akan berubah jika X (variabel bebas) diubah 1 unit.

\section{Tabel 1}

\section{Regresi Linier Berganda}




\section{Coefficients $^{\mathrm{a}}$}

\begin{tabular}{|c|c|c|c|c|c|c|}
\hline & \multirow[b]{2}{*}{ Model } & \multicolumn{2}{|c|}{$\begin{array}{c}\text { Unstandardized } \\
\text { Coefficients }\end{array}$} & \multirow{2}{*}{$\begin{array}{c}\text { Standardized } \\
\text { Coefficients }\end{array}$} & \multirow[b]{2}{*}{$\mathrm{T}$} & \multirow[b]{2}{*}{ Sig. } \\
\hline & & $\mathrm{B}$ & Std. Error & & & \\
\hline \multirow[t]{4}{*}{1} & (Constant) & 8.985 & 3.846 & & 2.336 & .022 \\
\hline & KREATIVITAS & .280 & .129 & .261 & 2.167 & .033 \\
\hline & $\begin{array}{l}\text { LINGKUNGAN } \\
\text { KELUARGA }\end{array}$ & .276 & .114 & .282 & 2.426 & .017 \\
\hline & JIWA ENTREPRENEUR & .218 & .106 & .225 & 2.049 & .044 \\
\hline
\end{tabular}

a. Dependent Variable: Niat Berwirausaha

Sumber :Data SPSS Tahun 2018

Berdasarkan hasil analisis regresi linier berganda pada tabel 1 dapat diperoleh suatu persamaan linier sebagai berikut :

$Y=8,985+0,280 X_{1}+0,276 X_{2}+0,218 X_{3}$

Dari persamaan garis linier berganda diatas dapat dijelaskan, yaitu :

$\mathrm{a}=8,985$ merupakan besarnya konstanta yang menyatakan bahwa jika variabel

independen (kreativitas, lingkungan keluarga dan jiwa entrepreneur)

sebesar 0 (nol), maka nilai variabel dependen (niat berwirausaha) sebesar 8,985 .

$\mathrm{b}_{1}=0,280$ adalah besarnya koefisien regresi variable bebas kreativitas $\left(X_{1}\right)$.

Artinya setiap ada penambahan atau kenaikan kreativitas $\left(\mathrm{X}_{1}\right)$ sebesar satu satuan, maka akan menambahkan variabel terikat niat berwirausaha (Y) sebesar 0,280 dengan anggapan variabel lainnya konstan.

$\mathrm{b}_{2}=0,276$ adalah besarnya koefisien regresi variabel bebas lingkungan keluarga

$\left(\mathrm{X}_{2}\right)$. Artinya setiap ada penambahan atau kenaikan lingkungan keluarga

$\left(\mathrm{X}_{2}\right)$ sebesar satu satuan, maka akan menambahkan variabel terikat niat berwirausaha (Y) sebesar 0,276 dengan anggapan variabel lainnya konstan.

$b_{3}=0,218$ adalah besarnya koefisien regresi variable bebas jiwa entrepreneur $\left(\mathrm{X}_{3}\right)$. Artinya setiap ada penambahan atau kenaikan jiwa entrepreneur $\left(\mathrm{X}_{3}\right)$ sebesar satu satuan, maka akan menambahkan variabel terikat niat berwirausaha (Y) sebesar 0,218 dengan anggapan variabel lainnya konstan.

B. Uji Hipotesis 
Pengujian hipotesis bertujuan untuk membuktikan hipotesis yang diajukan dalam penelitian, apakah diiterima atau ditolak. Uji hipotesis dalam penelitian ini terdiri dari uji $\mathrm{t}$ dan uji $\mathrm{F}$ yang dilakukan untuk mengetahui pengaruh variabel bebas kreativitas $\left(\mathrm{X}_{1}\right)$,lingkungan keluarga $\left(\mathrm{X}_{2}\right)$, jiwa entrepreneur $\left(\mathrm{X}_{3}\right)$ terhadap variabel terikat niat berwirausaha (Y) baik secara parsial maupun simultan

1. Hasil Uji t

Tabel 2

Hasil Uji Parsial

Coefficients $^{\mathrm{a}}$

\begin{tabular}{|c|c|c|c|c|c|c|}
\hline & \multirow{2}{*}{ Model } & \multicolumn{2}{|c|}{$\begin{array}{c}\text { Unstandardized } \\
\text { Coefficients }\end{array}$} & \multirow{2}{*}{$\begin{array}{c}\text { Standardized } \\
\text { Coefficients } \\
\text { Beta }\end{array}$} & \multirow[b]{2}{*}{$\mathrm{t}$} & \multirow[b]{2}{*}{ Sig. } \\
\hline & & $\mathrm{B}$ & Std. Error & & & \\
\hline \multirow[t]{4}{*}{1} & (Constant) & 8.985 & 3.846 & & 2.336 & .022 \\
\hline & KREATIVITAS & .280 & .129 & .261 & 2.167 & .033 \\
\hline & $\begin{array}{l}\text { LINGKUNGAN } \\
\text { KELUARGA }\end{array}$ & .276 & .114 & .282 & 2.426 & .017 \\
\hline & JIWA ENTREPRENEUR & .218 & .106 & .225 & 2.049 & .044 \\
\hline
\end{tabular}

a. Dependent Variable: Niat Berwirausaha

Berdasarkan tabel 2 dapat di ketahui bahwa variabel kreativitas $\left(\mathrm{X}_{1}\right)$ memiliki nilai sig. $\mathrm{t}<$ alpha yaitu sebesar 0,033 $<0,05$ dan $\mathrm{t}_{\text {hitung }}>$ $\mathrm{t}_{\text {tabel }}$ yaitu sebesar $2.167>1,9883$. Apabila sig. $\mathrm{t}<$ alpha atau $\mathrm{t}_{\text {hitung }}>$ $t_{\text {tabel, }}$ maka hipotesis $\left(\mathrm{H}_{\mathrm{o}}\right)$ ditolak dan hipotesis $\left(\mathrm{H}_{\mathrm{a}}\right)$ diterima. Dengan demikian dapat di simpulkan bahwa terdapat pengaruh yang signifikan antara kreativitas $\left(\mathrm{X}_{1}\right)$ terhadap niat berwirausaha $(\mathrm{Y})$ mahasiswa Pendidikan Ekonomi Semester VI STKIP PGRI Tulungagung tahun akademik 2017/2018.

Selanjutnya dapat di ketahui pula bahwa variabel lingkungan keluarga $\left(\mathrm{X}_{2}\right)$ memiliki nilai sig. $\mathrm{t}<$ alpha yaitu sebesar $0,017<0,05$ dan $t_{\text {hitung }}>t_{\text {tabel }}$ yaitu sebesar $2,426>1,9883$. Apabila sig. $t<$ alpha atau $t_{\text {hitung }}>t_{t a b e l}$, maka hipotesis $\left(\mathrm{H}_{\mathrm{o}}\right)$ ditolak dan hipotesis $\left(\mathrm{H}_{\mathrm{a}}\right)$ diterima. Dengan demikian dapat disimpulkan bahwa terdapat pengaruh yang signifikan antara lingkungan keluarga $\left(\mathrm{X}_{2}\right)$ terhadap niat berwirausaha 
(Y) mahasiswa pendidikan ekonomi semester VI STKIP PGRI Tulungagung tahun akademik 2017/2018.

Selanjutnya dapat di ketahui pula bahwa variabel jiwa entrepreneur $\left(\mathrm{X}_{3}\right)$ memiliki nilai sig. $\mathrm{t}<$ alpha yaitu sebesar $0,044<$ 0,05 dan $t_{\text {hitung }}>t_{\text {tabel }}$ yaitu sebesar $2,049>1,9883$. Apabila sig. $t<$ alpha atau $t_{\text {hitung }}>t_{\text {tabel }}$, maka hipotesis $\left(\mathrm{H}_{\mathrm{o}}\right)$ ditolak dan hipotesis $\left(\mathrm{H}_{\mathrm{a}}\right)$ diterima. Dengan demikian dapat disimpulkan bahwa terdapat pengaruh yang signifikan antara jiwa entrepreneur $\left(\mathrm{X}_{3}\right)$ terhadap niat berwirausaha (Y) mahasiswa pendidikan ekonomi semester VI STKIP PGRI Tulungagung tahun akademik 2017/2018.

2. Hasil Uji F

\section{Tabel 3}

Secara Simultan (Uji F)

ANOVA $^{b}$

\begin{tabular}{|ll|r|r|r|c|c|}
\hline \multicolumn{1}{|l|}{ Model } & Sum of Squares & Df & Mean Square & F & Sig. \\
\hline $1 \quad$ Regression & 998.001 & 3 & 332.667 & 23.464 & $.000^{\mathrm{a}}$ \\
& Residual & 1205.123 & 85 & 14.178 & & \\
Total & 2203.124 & 88 & & & \\
\hline
\end{tabular}

a. Predictors: (Constant), Jiwa Entrepreneur, Iingkungan Keluarga, Keativitas

b. Dependent Variable: Niat

Berwirausaha

Berdasarkan tabel 3. di ketahui bahwa signifikasi F 0,000 $<0,05$ dan $F_{\text {hitung }}$ $(23,464)>F_{\text {tabel }}(2,71)$ sehingga hipotesis nol ditolak dan hipotesis alternatif diterima. Oleh karena itu, dapat disimpulkan bahwa $\mathrm{H}_{\mathrm{o}}$ dalam penelitian ini di tolak dan $\mathrm{H}_{\mathrm{a}}$ di terima yang berarti terdapat pengaruh yang signifikan antara variabel kreativitas $\left(\mathrm{X}_{1}\right)$ dan lingkungan keluarga $\left(\mathrm{X}_{2}\right)$ dan jiwa entrepreneur $\left(\mathrm{X}_{3}\right)$ secara simultan terhadap niat berwirausaha (Y) mahasiswa Pendidikan Ekonomi Semester VI STKIP PGRI Tulungagung Tahun Akademik 2017/2018.

C. Uji Koefisien Determinasi

Tabel 4

Uji Korelasi dan Determinasi 


\begin{tabular}{|l|r|c|r|r|}
\hline Model & $\mathrm{R}$ & Rodel Summary \\
\hline 1 & $.673^{\mathrm{a}}$ & \multicolumn{1}{c|}{$\begin{array}{c}\text { Adjusted R } \\
\text { Square }\end{array}$} & $\begin{array}{l}\text { Std. Error of } \\
\text { the Estimate }\end{array}$ \\
\hline \\
a. Predictors: (Constant), Jiwa Entrepreneur, Iingkungan Keluarga, Keativitas \\
b. Dependent Variable: Niat Berwirausaha
\end{tabular}
?

Berdasarkan pada tabel di atas dapat dilihat bahwa koefisien korelasi (r) antara kreativitas, lingkungan keluarga dan jiwa entrepreneur terhadap niat berwirausaha adalah sebesar 0,673 . Sedangkan nilai koefisien determinasi $\left(\mathrm{r}^{2}\right)$ atau $\mathrm{R}$ Square dari persamaan regresi sebesar 0,453 dengan nilai koefisien determinasi sebesar 45,3\%. Hal ini menunjukkan bahwa 45,3\% perubahan variabel dependen niat berwirausaha (Y) di pengaruhi oleh perubahan variabel independen kreativitas $\left(\mathrm{X}_{1}\right)$, lingkungan keluarga $\left(\mathrm{X}_{2}\right)$ dan jiwa entrepreneur $\left(\mathrm{X}_{3}\right)$. Sedangkan sisanya $54,7 \%$ di pengaruhi oleh faktor-faktor lain yang tidak di teliti dalam penelitian ini.

\section{PEMBAHASAN}

Berdasarkan analisis data dengan menggunakan Statistical Product and Service Solution (SPSS)version 16 dapat dilihat dari tabel coefficients, di peroleh persamaan $\mathrm{Y}=\mathrm{a}+\mathrm{b}_{1} \mathrm{X}_{1}+\mathrm{b}_{2} \mathrm{X}_{2}+\mathrm{b}_{3} \mathrm{X}_{3}$ yaitu $\mathrm{Y}=8,985+0,280 \mathrm{X}_{1}+0,276 \mathrm{X}_{2}+$ $0,218 \mathrm{X}_{3}$ yang penjelasannya sebagai berikut: Constant merupakan konstanta yang besarnya 8,985 menyatakan bahwa jika variabel independen (kreativitas, lingkungan keluarga dan jiwa entrepreneur) sebesar 0 (nol), maka nilai variabel dependen (niat berwirausaha) sebesar 8,985. $\left(b_{1}\right)$ merupakan koefisien regresi dari $\mathrm{X}_{1}$ sebesar 0,280 yang berarti apabila variabel independen (kreativitas) meningkat 1 poin maka nilai pada variabel dependen (niat berwirausaha) akan meningkat sebesar 0,280 poin dengan asumsi yang lain tetap/konstan. ( $\left.b_{2}\right)$ merupakan koefisien regresi dari $\mathrm{X}_{2}$ sebesar 0,276 yang berarti apabila variabel dependen (lingkungan keluarga) meningkat 1 poin maka nilai pada variabel dependen (niat berwirausaha) akan meningkat sebesar 0,276 poin dengan asumsi yang lain 
tetap/konstan. $\left(b_{3}\right)$ merupakan koefisien regresi dari $\mathrm{X}_{3}$ sebesar 0,218 yang berarti apabila variabel dependen (jiwa entrepreneur) meningkat 1 poin maka nilai pada variabel dependen (niat berwirausaha) akan meningkat sebesar 0,218 poin dengan asumsi yang lain tetap/konstan.

Hasil penelitian ini didukung oleh penelitian yang dilakukan Lilis Maryati (2017) dalam jurnal yang berjudul "Pengaruh Pengetahuan Kewirausahaan dan Lingkungan Keluarga terhadap Niat Berwirausaha Siswa di SMK Negeri 4 Surakarta Tahun Ajaran 2016/2017'.Hasil penelitian ini adalah terdapat pengaruh yang positif dan signifikan antara pengetahuan kewirausahaan terhadap niat berwirausaha dengan nilai $\mathrm{t}_{\text {hitung }}=3,344>\mathrm{t}_{\text {tabel }}=1,665$ dan ada pengaruh yang positif dan signifikan antara lingkungan keluarga terhadap niat berwirausaha dengan nilai $t_{\text {hitung }}=5,392>t_{\text {tabel }}=1,665$. Serta terdapat pengaruh yang positif dan signifikan antara pengetahuan kewirausahaan dan lingkungan keluarga terhadap niat berwirausaha dengan nilai $F_{\text {hitung }}=21,749>F_{\text {tabel }}=2,372$. Maka dapat dikatakan bahwa secara simultan ada Pengaruh Pengetahuan Kewirausahaan dan Lingkungan Keluarga terhadap Niat Berwirausaha Siswa di SMK Negeri 4 Surakarta Tahun Ajaran 2016/2017.

Dalam penelitian ini, peneliti menambahkan dua variabel bebas (X) baru, yaitu: kreativitas dan jiwa entrepreneur. Berdasarkan analisis uji t terdapat pengaruh signifikan kreativitas terhadap niat berwirausaha $t_{\text {hitung }} 2,167>t_{\text {tabel }} 1,9883$ dengan nilai sig. 0,033 $<0,05$ dan terdapat pengaruh signifikan jiwa entrepreneur terhadap niat berwirausaha $t_{\text {hitung }} 2,049>1,9883$ dan nilai sig.0,044<0,05.

\section{PENUTUP}

\section{A. Kesimpulan}

Berdasarkan hasil penelitian dan pembahasan hasil penelitian yang telah dilakukan dapat disimpulkan bahwa :

1. Ada pengaruh yang signifikanvariabelkreativitas $\left(X_{1}\right)$ terhadap niat berwirausaha (Y)Mahasiswa Pendidikan Ekonomi Semester VI STKIP PGRI Tulungagung Tahun Akademik 2017/2018. 
Irwansyah, Subiantoro. Pengaruh Kreativitas, Lingkungan Keluarga Dan Jiwa Entrep...

2. Ada pengaruh yang signifikanvariabellingkungan keluarga $\left(\mathrm{X}_{2}\right)$ terhadap niat berwirausaha (Y)Mahasiswa Pendidikan Ekonomi Semester VI STKIP PGRI Tulungagung Tahun Akademik 2017/2018.

3. Ada pengaruh yang signifikanvariabeljiwa entrepreneur $\left(\mathrm{X}_{3}\right)$ terhadap niat berwirausaha (Y)Mahasiswa Pendidikan Ekonomi Semester VI STKIP PGRI Tulungagung Tahun Akademik 2017/2018.

4. Ada pengaruh yang signifikanvariabelkreativitas $\left(\mathrm{X}_{1}\right)$ dan lingkungan keluarga $\left(\mathrm{X}_{2}\right)$ dan jiwa entrepreneur $\left(\mathrm{X}_{3}\right)$ secara simultan terhadap niat berwirausaha (Y) Mahasiswa Pendidikan Ekonomi Semester VI STKIP PGRI Tulungagung Tahun Akademik 2017/2018.

\section{DAFTAR PUSTAKA}

Adnyana, I. G. L. A., \& Purnami, N. M. (2016). Pengaruh Pendidikan Kewirausahaan, Self Efficancy dan Locus of Control Pada Niat Berwirausaha. E-Jurnal Manajemen Unud, 5(2), 1160-1188.

Aini, M. P. N., Santosa, S., \& Hamidi, N. (2017). Pengaruh Lingkungan Keluarga dan Lingkungan Sekolah Terhadap Minat Berwirausaha. Pendidikan Akuntansi, FKIP Universitas Sebelas Maret Surakarta, 57126, Indonesia, 3(2), 1-10.

Alma, Buchari. 2011. Kewirausahaan. Penerbit CV Alfabeta, Bandung.

Anggraeni, B., \& Harnanik. (2015). Pengaruh Pengetahuan Kewirausahaan dan Lingkungan Keluarga Terhadap Minat Berwirausaha Siswa Kelas XI SMK Islam Nusantara Comal Kabupaten Pemalang. Jurnal Pendidikan Ekonomi Dinamika Pendidikan, X(1), 42-52

Etriyani, Y. E. (2014). Pengaruh Kreativitas, Peran Orang Tua, dan Efikasi Diri Terhadap Intensi Berwirausaha Siswa Kompetensi Keahlian Administrasi Perkantoran SMK Negeri 1 Pengasih. SKRIPSI.

Fahdli, S. M., Dr. Astri Gina, S.Si., M. S. ., \& Putri, M. K. (2017). Pengaruh Pendidikan Kewirausahaan Terhadap Niat Berwirausaha Mahasiswa ( Studi kasus pada Mahasiswa MBTI Angkatan 2013 Telkom University ) The Effect of Entrepreneurship Education on Entrepreneurial Intention ( Case Study on MBTI Students batch 2013 ). E-Proceeding, 4(3), 2480-2487.

Fatmawati, I. (2013). Pengaruh Kreativitas Berwirausaha dan Prestasi Belajar Kewirausahaan Terhadap Motivasi Berwirausaha Pada Mahasiswa Program Studi Pendidikan Akuntansi Fakultas Keguruan dan Ilmu Pendidikan 
Irwansyah, Subiantoro. Pengaruh Kreativitas, Lingkungan Keluarga Dan Jiwa Entrep...

Universitas Muhammadiyah Surakarta Angkatan 2010/2011. Naskah Publikasi.

Kasmir. 2009. Kewirausahaan. Jakarta: PT. Rajagrafindo Persada

Imam Ghozali, S.Psi., M. S., \& Dr. Alimatus Sahrah, M.M., M. S. (2015). Pengaruh Efikasi Diri Dan Kecerdasan Menghadapi Rintangan Terhadap Niat Berwirausaha Pada Mahasiswa Fakultas Ekonomi di Universitas Bangka Belitung, 7, 1-6.

Setiawan, D. (2016). Pengaruh Ekspektasi Pendapatan, Lingkungan Keluarga dan Pendidikan Kewirausahaan Terhadap Minat Berwirausaha. SKRIPSI.

Sugiyono, 2016.Metode penelitian pendidikan pendekatan kuantitatif, kualitatif dan R\&D. Bandung: Alfabeta.

Winardi, J. 2008. Entrepreneur dan Entrepreneurship.Penerbit Kencana Media

Groub. Jakarta 